\title{
頸動脈超音波検査による頸動脈プラークの組織性状診断 と脳梗塞発症との関係
}

\author{
半田伸夫 岡崎 裕 伊藤泰司 湯浅義人 杉谷義憲
}

星ヶ丘厚生年金病院脳血管内科

\section{Ultrasonographic Characterization of Carotid Plaque and Its Implications for Ischemic Cerebrovascular Events}

\author{
Nobuo HANDA, Yutaka OKAZAKI, Taiji ITOH, Yoshihito YUASA, Yoshinori SUGITANI
}

Stroke Unit, Internal Medicine, Hoshigaoka Kousei-Nenkin Hospital

The purpose of the study was to investigate the association between ischemic stroke and the ultrasonographic (US) characterization of carotid plaque on the basis of our original work and of a review of the literature.

Carotid plaque is known to be a reliable marker of ischemic stroke and systemic atherosclerosis. There is much evidence from secondary prevention trials to indicate a direct relationship between the surface and internal US characterization of carotid plaque and stroke. Moreover, in the primary prevention of stroke, the Cardiovascular Health Study showed that the risk of incident stroke was associated with two US features, hypoechoic internal carotid arterial plaque and an estimated internal carotid arterial stenosis of $50 \%-100 \%$, in asymptomatic adults aged 65 years. However, many studies that have compared the morphologic features of carotid plaque as revealed by both US studies and histology have shown a relatively low rate of detection of important features such as intraplaque hemorrhage. Furthermore, although severe carotid stenosis is associated with a higher risk of stroke events, the power of US to predict such events is limited by low incidence rates and low rate of progression.

We conclude that US plaque characterization should be used together with other risk factors in prospective natural history studies that aim to identify a subgroup of patients at high risk of stroke.

Key words : carotid artery disease, stroke, ultrasonography, plaque morphology

\section{はじめに}

動脈硬化がヒトにおいてどのように生じ，進展し，臓器 障害を引き起こすかについては未知の部分が多い．基礎的 な研究から血管壁への脂質や変性物質の沈着がスカベン ジャー受容体の発現により生じることが明らかとなった ${ }^{81}$. また冠動脈病変の進展が一定の速度で閉塞に向かうのでは なく，プラークの破綻というイベントを契機に一挙に閉塞 に向かうことが病理学や，血管内超音波検査の所見から臨 床例から明らかとなってきた ${ }^{2)}$. しかしながら同じ危険因子 を有しながら動脈硬化の進展の様式やその程度に差がある ことや臟器血管による差異などは未だに解明されていない， 虚血性脳血管障害を例にとって考えてみても，虚血の発症 は塞栓症（心原性，血管原性）なのか，局所での血栓性閉 塞なのか, 結論がつかないことが多い.
頸部血管, 特に頸部頸動脈はアテローム性動脈硬化の好 発部位であり, 従来より欧米では, 超音波法による評価が 最もポピュラーな評価法として沉用されている，頸部頸動 脈病変はアテローム血栓性脳梗塞の代表的病変で, 血管原 性塞栓症や, 閉塞や高度狭窄より生じる低潅流梗塞の原因 疾患として臨床上極めて重要な病変であると言われている。 では, 非侵襲的に頸動脈病変を観察することで, 動脈硬化 の何が解り, 脳梗塞発症解明に対してどのようなインパク トを与えたのであろうか. 本論文では, 頸動脈硬化と脳梗 塞についての関係について主に頸動脈プラークを中心とし て現在の知見を筆者らの従来までの研究と, 文献的な考察 よりまとめてみたいと思う。

\section{頸部頸動脈の超音波による評価方法}

血管壁を観察するために，必要な機器としては，国内外

Reprint request

半田伸夫：テ573-8511 枚方市星ヶ丘 4 丁目 8-1 星ヶ 丘厚生年金病院脳血管内科

Nobuo HANDA : Stroke Unit, Internal Medicine, Hoshigaoka Kousei-nenkin Hospital, 4-8-1 Hoshigaoka, Hirakata 573-8511, Japan 
Table 1 Normal values of IMT and the threshold of plaque

\begin{tabular}{llllll}
\hline & Poli $(1988)$ & Tell $(1989)$ & Salonen $(1988,90)$ & Handa $(1990)$ & ARIC (1994) \\
\hline Nomal & $0.55 \pm 0.07$ & $0.1 \sim 1.0$ & & $0.58 \pm 0.14$ & $0.4 \sim 1.43$ \\
Upper limit & 1.1 & $1.2(1.1)$ & 1.0 & 1.43 \\
Plaque & $2.0 \leqq$ & $1.1 \leqq$ & $2.0 \leqq$ & $1.1 \leqq$ & $1.5 \leqq$ \\
\hline
\end{tabular}

Units : mm, Values were mean $\pm S D$.

の超音波機器メーカーから頸部血管〜末梢血管専用プロー ブ（おもに duplex type で color flow image できるもの）を有 する超音波複合装置が数多く発売されている。これらはい ずれも $5 \mathrm{MHz}$ 以上 (7.5 MHz 前後) の中心周波数を持つ高解 像断層装置である。これらの装置を用いることにより0.2 $0.4 \mathrm{~mm}$ の深度分解能の画像を得ることが可能である. また 走査方向の水平解像度も超音波発信素子配列などの改良が 進み, 血管の縦断像を観察する際には超音波で観察される 血管壁といわれる内膜中膜複合体, intima-media complex （IMC）が連続的な二重構造として観察できる.

実際の検査手技としては, 超音波法の利点を生かし血管 を多面的に観察することが望ましい. 著者らは欧米での報 告を参考として被験者を坐位の状態とし, 頸動脈を斜め前 方より観察する前斜位, 横からの側面, 斜め後方から耳架 から下顎骨面より観察する後斜位の各縦断像と, 横断像を ルーチンに観察している。

評価できる項目は断層画像では血管径, 血管の走行, 血 管壁にあたる内膜中膜複合体の厚みとその性状, プラーク の厚みを含めた大きさとその性状, 血管内腔面の状態であ り, ドプラ検査では各部の血流速度および血流波形解析, カラードプラ, パワードプラでは実際の血流の有無と, 血 管壁と血流の相互関係などである.このうちこの項ではプ ラークの評価方法とその臨床的意義について記載する.

\section{血管壁の診断と評価}

血管壁は血管内腔面 1 層の低エコー輝度の部分と, その 外の高エコー輝度の 2 層として観察される. Pignoli らは 116 例の病理標本との比較から前者が内膜と中膜の複合像（内 膜中膜複合体；IMC）に後者が外膜と血管周囲の結合織から なることを報告した ${ }^{15}$. 著者等もこの報告を追試し確認して いる ${ }^{5)}$.

IMC の厚み（IMT）の正常值や評価に関しては多くの方法 が報告されている．欧米では ARIC studyの 15800 例での報 告が詳しい( ${ }^{6)}$.これらの結果を Table 1 にまとめた. 結果を まとめると, 総頸動脈の IMT は中央值が 0.6 から $0.8 \mathrm{~mm}$ で 0.1 から $0.15 \mathrm{~mm}$ の標準偏差をもち, 年齢とともに 0.01 $\mathrm{mm}$ から $0.015 \mathrm{~mm} / \mathrm{y}$ 増加する. IMC の正常上限については 様々な報告があるが, その症例数からいっても ARIC study の結果を引用することが妥当と考えられる. 95\% タイルの 正常上限は黒人男性 $>$ 白人男性 $>$ 黒人女性 $>$ 白人女性の順
で大きく, 総頸動脈で 45 才白人女性で $0.72 \mathrm{~mm}, 45$ 才黒人 男性で $0.90 \mathrm{~mm}, 65$ 才白人女性で $0.94 \mathrm{~mm}, 65$ 才黒人男性 で $1.43 \mathrm{~mm}$ である。この結果から ARIC cohort では $1.5 \mathrm{~mm}$ 以上を異常肥厚と判定している ${ }^{6)}$. 著者らは従来より正常 上限を $1.0 \mathrm{~mm}$ とし $1.1 \mathrm{~mm}$ 以上を異常肥厚としてきてい る $^{5)}$. 従来までのIMT の正常上限と, プラークの基準を Table 1 に示す ${ }^{10,17 ~ 20)}$.

\section{プラークの評価}

プラークの存在する頻度は著者らの施設での成績では脳 血管障害群で $59 \%$, 脳血管障害以外で $41 \%$ の結果であっ た . ARIC study では 15800 人の一般住民の検診の結果, 分 岐部（頸動脈洞）に $20 \%$, 総頸動脈に $5.4 \%$, 内頸動脈に 8.5 9.8\%の頻度でプラークを認めた。この頻度は年齢に より増加し 40 才代 $21.5 \%, 50 ５ 4$ 才 $28.7 \% ， 55 ５ 9$ 才 $39.6 \%$ ，60６4才 $47.1 \%$ となっていた ${ }^{6)}$. また一般住民で の病変の重症度に関しての成績では, O‘Leary らは 5201 人 を調べ，75\% 狭窄以上は男性で $2.3 \%$, 女性で $1.1 \%, 50$ $75 \%$ の中程度狭窄は男性で $5.3 \%$, 女性で $4.0 \%$ にすぎな いが, 極軽度の病変（1.1mm 以上）を含めると男性の $75 \%$, 女性の $62 \%$ が病変を有すると報告した ${ }^{14)}$ 。結果をまとめる と， 60 才以上の高齢者では $50 \%$ 以上にプラークを有する が， $50 \%$ 狭窄以上では $5 \%$ 前後， $70 \%$ 狭窄以上では $2 \%$ 前後の頻度と考えられる ${ }^{1)}$.

プラークの部位：プラークは頸動脈洞から内頸動脈側 に多く認められる。前述のARIC studyの結果では総頸動 脈に $5.4 \%$, 䁰動脈洞 $19.4 \%$, 内頸動脈8.5\%であった ${ }^{14)}$.

Kagawa らの頸動脈内膜剥離術（CEA）の成績でも全 70 病 変の内, 総頸動脈に $7.4 \%$, 頸動脈洞から内頸動脈に $85.3 \%$, 内頸動脈のみ $7.4 \%$ であった ${ }^{7)}$.

プラークの性状診断には, 表面性状の診断, 内部性状の 診断がある. 病変の表面性状としては, 平滑な表面性状と, 不整な表面性状があり, 陥凹が深い場合は潰啺と診断され る.この潰瘍性病変の診断は以外と困難で, 従来の血管撮 影で $50 \%$ 程度, 超音波法で $80 \%$ 前後の診断精度と考えら れている，潰瘍の定義は様々だが，陥凹深度が $1.5-2 \mathrm{~mm}$ 以上ある場合の正診率は高いと考えられている ${ }^{21}$. Kagawa らの論文での診断率は B - mode が $93.8 \%$ で angiograpy が $60.4 \%$ である ${ }^{7)}$. Widder らは彼らの論文の中でB-mode 法による組織性状診断の正診率をまとめていて, 
Table 2 Accuracy of ultrasonographic characterization of carotid plaque

\begin{tabular}{lrrrrr}
\hline & & $\mathrm{N}$ & sensitivity & specificity & accuracy \\
\hline Ulceration & & & & & \\
Reilly et al & 1983 & 50 & $42 \%$ & $100 \%$ & $58 \%$ \\
Farber et al & 1984 & 29 & $72 \%$ & $75 \%$ & $72 \%$ \\
Widder+Hamann & 1984 & 48 & $75 \%$ & $83 \%$ & $79 \%$ \\
$\quad$ Fischer et al & 1985 & 28 & $30 \%$ & $58 \%$ & $42 \%$ \\
O'Donnell et al & 1985 & 79 & $89 \%$ & $87 \%$ & $87 \%$ \\
O'Leary et al & 1987 & 47 & $39 \%$ & $72 \%$ & $60 \%$ \\
Widder et al & 1989 & 165 & $29 \%$ & $50 \%$ & $43 \%$ \\
Kagawa et al & 1996 & 64 & $94 \%$ & $90 \%$ & $93 \%$ \\
Intraplaque hemorrhage & & & & & \\
Reilly et al & 1983 & 50 & $83 \%$ & $79 \%$ & $82 \%$ \\
O'Donnel et al & 1985 & 79 & $93 \%$ & $84 \%$ & $87 \%$ \\
Bluth et al & 1986 & 53 & $94 \%$ & $88 \%$ & $90 \%$ \\
Widder et al & 1989 & 165 & $72 \%$ & $80 \%$ & $75 \%$ \\
\hline
\end{tabular}

Table 2 にその結果と Kagawa らの報告をまとめて示す.

内部の組織性状はその輝度分布が均質 (homogenous) か, 不均質 (heterogeous) かの 2 つ, とエコー輝度から低（low or hypo - ), 等 (iso - ), 高 (hyper - ) の 3 つの組み合わせ で表現されることが多い. Gray-Weale らの報告では type 1： 薄いエコー輝度の高い表皮を有する低エコ一輝度の病変, type 2 : 殆どが低エコー輝度で, 一部に高エコー輝度があ るもの, type 3 : 低エコー輝度病変が $25 \%$ 以下で, 大半が 高エコー輝度の病変, type 4 : 殆ど均質の高エコー輝度病 変と分類した。この分類はヨーロッパで多く用いられてい る.この分類にさらに type 5 : 音響㓌影のため病変の評価 ができない病変を加えているグループもある3!.これに動脈 硬化性病変の病理所見を当てはめていくことになる. 病理 所見は一般に脂肪線状 (fatty streak), 線維性肥厚 (fibrous plaque), 複合病変 (complicated lesion) の3つに分類され, 血管病変発症の意味からは病変の増大因子としての複合病 変内の籿種の破綻とプラーク内出血が注目されている 2 .

その他の組織性状診断法としては, 石灰化している病変 を mineralized plaque, エコー輝度の高いものを hard plaque, 低いものを soft plaque などと称している論文もあるが, 現実 にエコーでは硬さを評価できないので hard, soft などの表 現は適切ではないように思われる。

線維性肥厚では均質高輝度病変に, 複合病変では不均質 病変内に囊胞状変化が観察される場合は樕種の自壊や潰瘍 形成が存在することが多い. Kagawaらは CEA を施行した 64 例で詳細な検討を行い, 8 割は不均質病変でその 6 割は 複合性病変であったと報告した。均質性で輝度が等しいか 高い場合は線維性肥厚が多いと報告している融。また西谷 らはCEAを行った 22 例 24 病変に対して術前超音波検査を し, 低輝度病変は全例プラーク内出血を認め, 逆に高輝度 病変ではプラーク内出血は認めなかったとの結果を報告し ている. またプラーク内出血が 24 病変中 7 病変に認められ, そのうち 6 例 $(87.5 \%)$ が有症候性であったとしている ${ }^{13)}$. 一方で複合病変の中で, アテローマの自壊部分とプラーク
内出血との鑑別は困難であるとの報告も多い ${ }^{11)}$.

\section{プラークの自然歴}

非侵襲的に動脈硬化を評価できるため, 頸動脈硬化症の 自然歴を見ることが可能である. 我々の検討によればプラー クは年間 $0.05 \mathrm{~mm}$ 肥厚する. 特に $3.0 \mathrm{~mm}$ 未満の厚みの病変 ではほぼ一定の速度で肥厚する。ただ $3.0 \mathrm{~mm}$ を超える大き な病変の場合, その進展様式は様々であった. $1.1 \mathrm{~mm}$ 以上 の病変の総和である Plaque score でみると年間 $0.5 \mathrm{~mm}$ ずつ 増悪することになる (Fig .1,2). Muluk SC らの報告は 1004 例を追跡したもので，年間狭窄率で $9.3 \%$ ずつ比較的着実 に進展すると報告している(2)。

\section{超音波による頸動脈病変評価で脳梗塞発症の予測が可能か？}

高度の頸動脈病変を有する場合は, 脳梗塞発症のリスク は高いことは明らかである。ただし, 病変の性状や, 病変 の進展度での脳梗塞発症の予測に関しては脳梗塞の発症の メカニズムが多岐にわたるため困難であろう。 Lewis らの 報告では, 無症候性頸動脈病変例で頸動脈病変の進展から 脳梗塞発症を予測することは困難であるとした ${ }^{9 !}$.他にも 同様の論文は多い。これは, 例えば心房細動がある頸動脈 病変例で, 脳梗塞発症する場合のように，他の原因，他の 領域での脳梗塞を全て含めて論ずるために起こる問題のよ うに思われる。

このため, Cardiovascular Health Study では, 心原性塞栓症 をできうる限り除外した多数例の前向き調査を行った. 1998 年にPolak らが発表した 4886 人の前向き調査がこれである. 彼らは 65 歳以上の無症候の 4886 人を 3.3 年間追跡調査し た ${ }^{16)}$ 。 ドプラ所見は peak systolic velocity $>=1.5 \mathrm{~m} / \mathrm{s}$ で 50 $100 \%$ 狭窄とした. IMT が $1.5 \mathrm{~mm}$ より厚いものをプラーク と判定, 低輝度, 等輝度, 高輝度の 3 群に分類, 低輝度は 血管内腔と同じ，等輝度は周辺軟部組織と同じ，高輝度は 等輝度よりも高いエコー輝度のものとしている. $50 \%$ 狭窄以 上の頸動脈病変の頻度は $5.42 \%$ であり, 前出の一般住民対 


\section{Changes of max-IMT in all cases}

1 st: $2.1 \pm 1.2 \Rightarrow 2$ nd $2.2 \pm 1.2(p<0.1)$

initial IMT $<3$

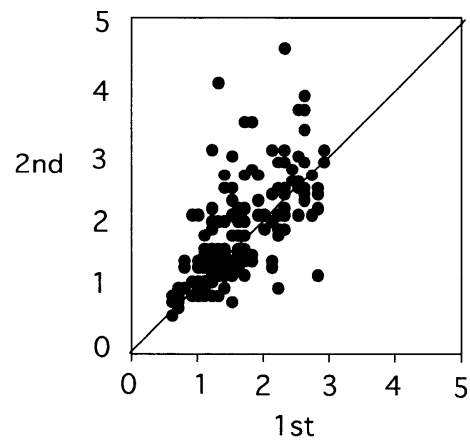

initial IMT > 3

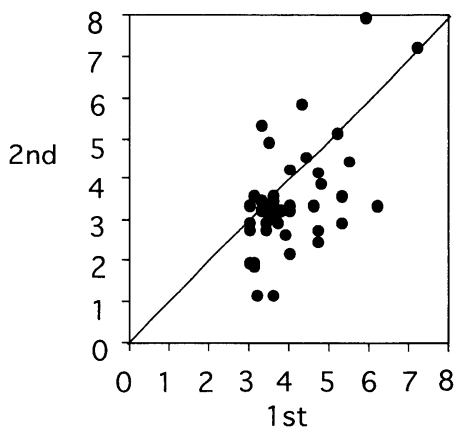

Fig. 1 Annual change of carotid intima-media thickness (IMT)

The figure shows the annual change of carotid IMT in 214 patients. Max-IMT indicates the maximum thickness of IMT in theindividual. Left panel : most plaques below $3.0 \mathrm{~mm}$ in thickness progressed annually.

Right panel : a variety of changes occur in severe lesions larger than $3.0 \mathrm{~mm}$ in thickness.

\section{Changes of carotid atherosclerosis in all cases}

1 st: $4.5 \pm 4.9 \Rightarrow 2$ nd: $5.3 \pm 5.0(p<0.001)$

initial PS $<10$

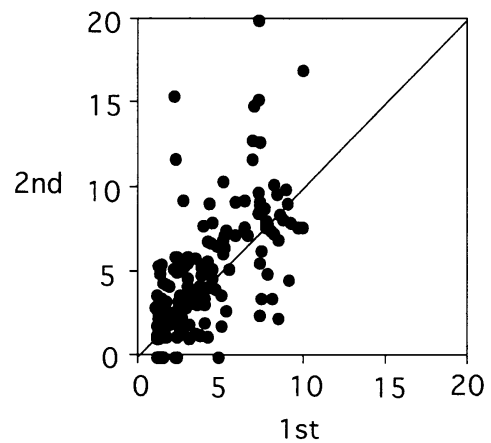

initial PS > 10

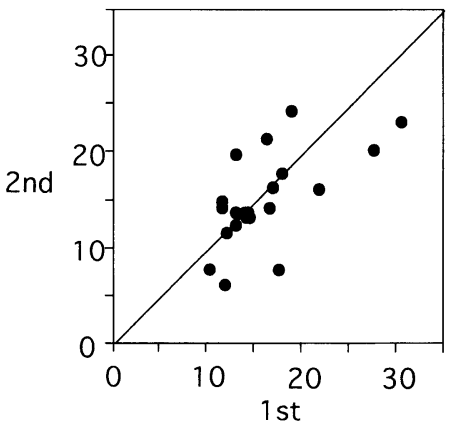

Fig. 2 Annual change of plaque score

Plaque score is the sum of all carotid plaques thicker than $1.1 \mathrm{~mm}$.

Left panel : most cases with plaque score less than 10 showed annual increases in the lesions.

Right panel : a variety of changes occur with plaque scores over 10 .

象の頻度に一致している。この研究では，脳出血や心原性 脳塞栓症は除外した結果，追跡調査期間内に 104 人の脳血 栓が発症した $(2.1 \%)$. 発症に寄与する因子として，年齢， 糖尿病, 血圧上昇などと共に, $50 \%$ 以上の頸動脈狭窄や, 低輝度プラークの存在が明らかとなった。これはNASCET やECST の結果では脳卒中発症が $10 \%$ 以上と高率であるこ とに比べると極めて低い発症頻度であるが, 症候性高度病 変症例の 2 次予防を目的としたこれらの研究と根本的に異 なる。

頸動脈病変と脳血管障害の発症に関しては, 血管撮影を 基本検査としている NASCET や ECST の結果より, 高度狭 窄病変での虚血性脳血管障害の発症が高頻度であることが 報告されている．また著者らが行った OSACA studyでの追 跡調査では, 高度狭窄例や, 潰瘍形成例での再発が高いこ
とが示めされた。すなわち高度病変は病変なしに比し 9 倍 再発率が高く, 潰瘍病変群は無し群に比べ 4 倍再発率が高 いとの結果であった ${ }^{4}$.

\section{プラークの破綻，プラーク内出血と虚血性イベントの発生}

Acute coronary syndrome の発症にはプラーク内出血を基盤 としたプラークの破綻によりひきおこされることが示され， 脳梗塞の発症においても同様のメカニズムが存在すること が疑われている．頸部頸動脈プラークにおいても閉塞機転 や, 血管原性塞栓症の発症にプラーク内出血やプラークの 破綻が大いに関係があるものと思われる．冠動脈を非侵襲 的に経時的に評価できる方法はそしいが，頸動脈に関して は超音波断層法にて容易に観察できる。このため様々な報 告がなされていて, 前述の如く低輝度の高度病変の場合に 
は症候性になることが多いとの報告が主体である．ただし， プラーク内出血と脂質に富んだプラークとの鑑別は困難で あるため, 病変の発症にプラーク内出血やプラークの破綻 がどの程度関与しているかについては明確な結論が出ない ように思われる，繰り返しになるが，現時点で明らかなこ とは, 高度病変でプラーク内出血の頻度が高い, 低エコー 輝度病変で脂肪性分に富んだプラークやプラーク内出血の 頻度が高いということになる21)。

\section{まとめ}

動脈硬化の自然歴を頸動脈病変を超音波で観察すること で何が解ったのか. また脳梗塞の発症に関して頸動脈硬化 がどのように関与するのかというような疑問に関して，か なりの結論が出てきたように思われる．頸動脈病変の進展 は当初はゆっくりしたものであるが, $3.0 \mathrm{~mm}$ 前後の大き さ，70\% 以上の狭窄になるとある種の病変は急速に進展し て acute coronary syndrome と同様にイベント発症するように なる，病変の性状としては低エコー輝度の病変で狭窄度の 高いもの，表面の性状が著しく不整形のものは急速に進展 してイベントをおこしやすいようである，症候性頸動脈病 変の組織学的な裹付けとしては, 全例が必ずしもプラーク 内出血やプラークの破綻をきたしているわけではなく, 現 時点で頸動脈超音波検査のみでイベント発症を予知し診断 することはもちろんできない.しかしながら，一次予防に おいても狭窄率のみでなく, 頸動脈病変のエコー輝度や表 面性状などの情報は，イベント発症の危険因子として独立 した因子であることは明らかであるので，高血圧，糖尿病， 高脂血症，契煙歴，強い脳梗塞の家族歴などがあるばあい に頸動脈を評価することの意義は極めて高いものと思われ る.

\section{文献}

1 ) Fine-Edelstein JS, Wolf PA, O'Leary DH, Poehlman H, Belanger AJ, Kase CS, D'Agostino RB : Precursors of extracranial carotid atherosclerosis in the Framingham study. Neurology 44 : 1046-1050, 1994

2 ) Fuster V, Badimon L, Badimon JJ, Chesebro JH : The pathogenesis of coronary artery disease and the acute coronary syndromes. $\mathrm{N}$ Engl $\mathrm{J}$ Med $326: 242-250,1992$

3 ) Geroulakos G, Hobson RW, Nicolaides A: Ultrasonographic carotid plaque morphorogy in predicting stroke risk. Br J Surg 83 : 582 - 587, 1996

4) Handa N, Matsumoto M, Maeda H, Hougaku H, Kamada T : Ischemic stroke events and carotid atherosclerosis. Results of the Osaka follow-up study for ultrasonographic assessment of carotid atherosclerosis (the OSACA study). Stroke 26: 1781 - 1786, 1995

5 ) Handa N, Matsumoto M, Maeda H, Hougaku H, Ogawa S, Fukunaga R, Yoneda S, Kimura K, Kamada T : Ultrasonic evaluation of early carotid atherosclerosis. Stroke 21: 1567-1572, 1990

6 ) Howard G, Sharrett AR, Heiss G, Evans GW, Chambless LE, Riley WA, Burke GL : Carotid artery intimal-medial thickness distribution in general populations as evaluated by B-mode ultrasound. Stroke 24 : 1297-1304, 1993

7 ) Kagawa R, Moritake K, Shima T, Okada Y : Validity of B-mode ultrasonographic findings in patients undergoing carotid endarterectomy in comparison with angiographic and clinicopathologic features. Stroke $27: 700$ - 705, 1996

8 ) Kodama T, Freeman M, Rohrer L, Zabrecky J, Matsudaira P, Krieger M : Type 1 macrophage scavenger receptor contains $\alpha$-helical and collagen-like coiled coils. Nature $343: 531-535,1990$

9 ) Lewis RF, Abrahmowicz M, Cote R, Battista RN : Predictive power of duplex ultrasonography in asymptomatic carotid disease. Ann Intern Med 127: 13 - 20, 1997

10) Li R, Dancan BB, Metcalf PA, Crouse JR 3rd, Sharrett AR, Tyroler HA, Barnes R, Heiss G: B-mode-detected carotid artery plaque in a general population. Stroke $25: 2377-2383,1994$

11) Montauban van Swijndregt AD, Elbers HR, Moll FL, de Letter J, Ackerstaff RG : Ultrasonographic characterization of carotid plaques. Ultrasound Med Biol 24 : 489 - 493, 1998

12) Muluk SC, Muluk VS, Sugimoto H, Rhee RY, Trachtenberg J, Steed DL, Jarrett F, Webster MW, Makaroun MS: Progression of asymptomatic carotid stenosis : a natural history study in 1004 patients. J Vasc Surg 29: $208-214,1999$

13）西谷和敏、上田 伸、松本圭蔵、阿川昌仁、高瀬憲作：超音波 による頸部頸動脈狭窄症の術前評価 . Neurosonology 9: 68 - 73, 1996

14) O‘Leary DH, Polak JF, Kronmal RA, Kittner SJ, Bond MG, Wolfson SK Jr, Bommer W, Price TR, Gardin JM, Savage PJ : Distrubution and correration of sonographycally detected carotid artery disease in the Cardiovascular Health Study. Stroke 23 : 1752-1760, 1992

15) Pignoli P, Tremori E Poli A, Oreste P, Paoletti $R$ : Intimal plus medial thickness of the arterial wall: a direct measurement with ultraound imaging. Circularion 74 : 1399-1406, 1986

16) Polak JF, Shemanski L, O'Leary DH, Lefkowits D, Price TR, Savage PJ, Brand WE, Reid C:Hypoechoic plaque at US of the carotid artery : An independent risk factor for incident stroke in adults aged 65 years or older. Cardiovascular Health Study. Radiology 208: 649 - 654, 1998

17) Poli A, Tremori E, Colombo A, Sirtori M, Pignoli P, Paoletti R : Ultrasonographic measurement of the common carotid artery wall thickness in hypercholesterolemic patients. A new model for the quantitation and follow-up of preclinical atherosclerosis in living human subjects. Atherosclerosis $70: 253-261,1988$

18) Salonen R, Salonen JT : Progression of carotid atherosclerosis and its determinants: A population-based ultrasonography study. Atherosclerosis 81: 33-40, 1990

19) Salonen R, Seppanen K, Rauramaa R, Salonen JT : Prevalence of carotid atherosclerosis and serum cholesterol levels in eastern Finland. Arteriosclerosis 8: 788-792, 1988

20) Tell GS, Howard G, McKinney WM : Risk factors for site specific extracranial carotid artery plaque distribution as measured by B-mode ultrasound. J Clin Epidemiol 42 : 551-559, 1989

21) Widder B, Paulat K, Hackspacher J, Hamann H, Hutschenreiter S, Kreuter C, Ott F, Vollmar J: Morphorological characterization of carotid artery stenoses by ultrasound duplex scanning. Ultrasound Med Biol 16 : 349 - 354, 1990 